\title{
Chemical Composition and in Vitro Biological Activities of White Mulberry Syrup during Processing and Storage
}

\author{
Nguyen Quang Trung, Nguyen Thi Luyen, Vu Duc Nam, Nguyen Tien Dat \\ Center for Research and Technology Transfer, Vietnam Academy of Science and Technology, \\ 18-Hoang Quoc Viet, Cau Giay, Hanoi, Vietnam \\ *Corresponding author: ngtiend@imbc.vast.vn
}

Received August 19, 2018; Revised October 22, 2018; Accepted November 15, 2018

\begin{abstract}
Mulberry fruit contains health-promoting polyphenols and is consumed in processed products such as juices, syrups, liquors, molasses, and jams. In Vietnam, syrups prepared from mulberry fruits and sugar have long been used in food preparation. We investigated the changes in chemical composition and biological activities of mulberry syrup during its processing and storage. The toxic metals lead and cadmium were detected in mulberry syrup at levels below regulatory limits. Prolonged storage in glass containers, from which toxic metals could leach into the syrup, could be a risk to the health of consumers. The total phenolic (TPC), flavonoid (TFC), and anthocyanin (TAC) contents varied during processing and decreased significantly after day 45. The 1,1-diphenyl-2picryl-hydrazyl activity of the mulberry syrup was correlated with its TPC, TFC, and TAC values, and anthocyanins were responsible for the inhibition of nitric oxide production. The magnitude of inhibition of $\alpha$-glucosidase and $\alpha$ amylase was linearly correlated with the TFC and TAC values of the mulberry syrup. The quality of the mulberry syrup was maintained during storage for 30 days but decreased thereafter.
\end{abstract}

Keywords: Morus alba, mulberry, mulberry syrup, phenolic, anthocyanin

Cite This Article: Nguyen Quang Trung, Nguyen Thi Luyen, Vu Duc Nam, and Nguyen Tien Dat, "Chemical Composition and in Vitro Biological Activities of White Mulberry Syrup during Processing and Storage.” Journal of Food and Nutrition Research, vol. 6, no. 10 (2018): 660-664. doi: 10.12691/jfnr-6-10-7.

\section{Introduction}

The mulberry belongs to the genus Morus (family Moraceae) and is distributed worldwide. Three main species of mulberry, white (Morus alba), black (Morus nigra), and red (Morus rubra) mulberry, are cultivated for fruit production. Mulberry fruit is an important foodstuff as it exerts antioxidant, anticancer, antidiabetic, anti-inflammatory, anti-obesity, hypolipidemic, and neuroprotective effects $[1,2]$. These activities are mediated by the anthocyanins, flavonoids, phenolic acids, terpenoids, and alkaloids in mulberry fruit $[3,4]$. Anthocyanins, which determine the color of mulberry fruit, have antioxidant, anti-inflammatory, antitumor, and antidiabetic activities. Cyanidin-3-O-glucoside (C3G) and cyanidin-3-O-rutinoside (C3R) are the most abundant anthocyanins in mulberry fruit [5,6,7]. In Vietnam, mulberry fruit has been used for thousands of years as a foodstuff and medicine. In Vietnamese traditional medicine, mulberry fruits are thought to improve eyesight, be effective against insomnia and cough, prevent the whitening of hair, ameliorate intestinal problems, and protect against liver damage [8]. Mulberry fruit has a short harvesting season and is sensitive to storage and transport due to its high water content (> 80\%). Therefore, mulberry fruit is used to make wine, syrup, juice, and jam or dried and added to ice cream, cake, and yogurt. Syrup is one of the most popular processed mulberry products in Vietnam. Fresh mulberry fruit is mixed with cane sugar in a ceramic or glass bottle and stored for at least 2 weeks to produce mulberry syrup. The bottled syrup can be stored for several months and then consumed $[9,10]$. However, prolonged storage at ambient temperatures may reduce the quality of the syrup. Therefore, we evaluated the changes in chemical composition and in vitro biological activities of mulberry syrup during storage.

\section{Materials and Methods}

\subsection{Chemicals and APPARATUS}

Folin-Ciocalteu's phenol reagent, gallic acid, quercetin, 2,2-diphenyl-1-picrylhydrazyl (DPPH), ascorbic acid, celastrol, acarbose were purchased from Sigma-Aldrich (St. Louis, MO, USA). The $\mathrm{pH}$ was measured with a $\mathrm{pH}$ meter (pH100, YSI, USA). Chemical contents were determined using a V-630 UV/VIS spectrophotometer (JASCO, Japan). Heavy metals were analyzed in a 7900 ICP-MS apparatus (Agilent Technology). Absorbances of the biological assays were read in an xMark microplate reader (Biorad, USA). 


\subsection{Mulberry Samples}

Fresh mulberry fruits were harvested from a white mulberry field in Phuc Tho commune, Hanoi, Vietnam during the ripening time, April 2018. The ripe and undamaged fruits (almost deep purple color) were manually selected and washed with tap water and then let drain in a sieve.

\subsection{Syrup Preparation}

The mulberry syrup was prepared from $1 \mathrm{~kg}$ of mulberry fruits and $0.5 \mathrm{~kg}$ of cane sugar according to a homemade procedure [10]. Into a $2 \mathrm{~L}$ glass jar with screw cover, alternately place a layer of fruit, then sprinkle with a layer of sugar. Cap the jar and let the mixture to freely ferment at room temperature $\left(25-30^{\circ} \mathrm{C}\right)$. After a period time at $15,30,45,60$ and 90 days, the syrup in each jar was homogenized by shaking and a volume of syrup was taken out. The syrup sample was centrifuged at $2500 \mathrm{rpm}$ for $10 \mathrm{~min}$ and the supernatant was used for evaluation of chemical compositions and biological activities. Samples were prepared in triplicate from three independent processing batches.

\subsection{Determination of Total Phenolic Content (TPC)}

The total polyphenol content was determined by the Folin-Ciocalteu method according to International Organization for Standardization (ISO) 14502-1 guidelines [11]. The result was calculated based on the slope from serial dilution of a gallic acid standard. Results were expressed as gallic acid equivalents (GAE) $\mathrm{mg} \mathrm{L}^{-1}$.

\subsection{Determination of Total Flavonoid Content (TFC)}

The total flavonoids in syrup were determined by mixing $0.5 \mathrm{~mL}$ of syrup with $0.3 \mathrm{~mL}$ of $10 \% \mathrm{AlCl} 3$ solution, $0.2 \mathrm{~mL}$ of $1 \mathrm{M}$ CH3COONa solution and $4 \mathrm{~mL}$ distilled water. After $15 \mathrm{~min}$ in darkness, the absorbance of the mixture was measured at $430 \mathrm{~nm}$ [12]. Quercetin was used as the standard. The results were expressed in $\mathrm{mg}$ of quercetin equivalents $(\mathrm{QE})$ per $\mathrm{L}$ of syrup.

\subsection{Determination of Total Anthocyanin Content (TAC)}

Total anthocyanins were determined using the $\mathrm{pH}$ differential method [13]. Syrup solutions were adjusted to $\mathrm{pH} 1.0$ and 4.5 and then absorbances were measured at 520 and $700 \mathrm{~nm}$. The TAC was based on C3G molar absorptivity of 26,900 and molecular weight of 449.2, and was expressed as C3G equivalent $\mathrm{mg} \mathrm{L}^{-1}$.

\subsection{Determination of Toxic Metal Content}

Heavy metal measurements were carried out using inductively coupled plasma-mass spectrometry [14]. Syrup $(1 \mathrm{~mL})$ was transferred into the digestion vessel, to which was added $3 \mathrm{~mL}$ of $65 \% \mathrm{HNO}_{3}$. The samples were then digested in a microwave oven at $210{ }^{\circ} \mathrm{C}$ for $15 \mathrm{~min}$. After cooling to ambient temperature, the reactors were opened, and the content was quantitatively transferred into a $50 \mathrm{ml}$ volumetric flask and brought to the volume with ultrapure water. All digested solutions were analyzed by ICP-MS. The operating conditions were: RF power: $1600 \mathrm{~W}$; sample depth $10 \mathrm{~mm}$; nebulizer gas flow rates: $0.7 \mathrm{~L} \mathrm{~min}^{-1}$; auxiliary gas flow: $0.3 \mathrm{~L} \mathrm{~min}^{-1}$; standard spray chamber temperature: $2^{\circ} \mathrm{C}$; rinse time $20 \mathrm{~s}$. Data acquisition was performed in spectrum analysis and full quant mode. Mass calibration and detector cross-calibration were performed according to the manufacturer's instructions using the prescribed solutions obtained from Agilent. Multi-element standards were prepared in-house by mixing of certified, traceable, ICP grade single element standards (Sigma Aldrich) that were subsequently diluted for analysis.

\subsection{DPPH Radical Scavenging Activity}

The antioxidant activity of the syrup was evaluated by its scavenging capacity of the 2,2-diphenyl-1-picrylhydrazyl (DPPH) radical [15]. Briefly, syrup solution $(20 \mu \mathrm{L})$ was mixed with $180 \mu \mathrm{L}$ of $150 \mu \mathrm{M}$ DPPH solution in a 96well plate. The plate was incubated in the dark at room temperature for $30 \mathrm{~min}$. Then, the absorbance of the reaction mixture was measured at $520 \mathrm{~nm}$ on a microplate reader. Ascorbic acid (vitamin $\mathrm{C}$ ) was used as the positive control. The antioxidant capacity was expressed as ascorbic acid equivalent (AAE) $\mathrm{mg} \mathrm{L}^{-1}$.

\subsection{Assay for Inhibition of nitric Oxide (NO) Production}

The effects of syrup on the NO production in LPSstimulated RAW264.7 cells were evaluated as previously described [16]. The cells were seeded in 96-well plate at $2 \times 10^{5}$ cells/well and incubated for $12 \mathrm{~h}$. The plates were pretreated with $20 \mu \mathrm{L}$ syrup for $30 \mathrm{~min}$ and then incubated for another $24 \mathrm{~h}$ with or without $1 \mu \mathrm{g} \mathrm{mL}^{-1} \mathrm{LPS}$. $100 \mu \mathrm{l}$ of the culture supernatant were transferred to other 96-well plate and $100 \mu \mathrm{l}$ of Griess reagent were added. The absorbance of the reaction solution was read at $570 \mathrm{~nm}$. Celastrol was used as a positive control. The inhibition was expressed as celastrol equivalent (CE) $\mathrm{mg} \mathrm{L}^{-1}$.

\subsection{Assay for Inhibition of Digestive Enzymes $\alpha$-glucosidase and $\alpha$-amylase}

The inhibitory effects against $\alpha$-glucosidase and $\alpha$-amylase enzymes were evaluated as previously described [17]. The antidiabetic agent, acarbose, was used as positive. Briefly, the syrup $(10 \mu \mathrm{L})$ and $0.5 \mathrm{U} \mathrm{mL}^{-1}$ $\alpha$-glucosidase $(40 \mu \mathrm{L})$ were mixed in $110 \mu \mathrm{L}$ of $0.1 \mathrm{M}$ phosphate buffer ( $\mathrm{pH} 7.0$ ). After 5 min pre-incubation, 5 $\mathrm{mM} p$-nitrophenyl- $\alpha$-D-glucopyranoside solution $(40 \mu \mathrm{L})$ was added and the solution was incubated at $37^{\circ} \mathrm{C}$ for $30 \mathrm{~min}$. The absorbance of released 4-nitrophenol was measured at $405 \mathrm{~nm}$. For $\alpha$-amylase inhibition assay, the sample $(10 \mu \mathrm{L})$ and 0.5 unit $\mathrm{mL}^{-1} \alpha$-amylase $(50 \mu \mathrm{L})$ were mixed in $100 \mu \mathrm{L}$ of $0.1 \mathrm{M}$ phosphate buffer ( $\mathrm{pH} 7.0$ ). After $5 \mathrm{~min}$ pre-incubation, $50 \mu \mathrm{L}$ of substrate solution (2-chloro-4-nitrophenyl- $\alpha$-D-maltotrioside dissolved in phosphate buffer, $\mathrm{pH}$ 7.0) was added and the solution was 
incubated at $37^{\circ} \mathrm{C}$ for $15 \mathrm{~min}$. The absorbances were then measured at $405 \mathrm{~nm}$. The enzyme inhibitory activities were expressed as acarbose equivalent (AE) $\mathrm{mg} / \mathrm{L}$. The IC $_{50}$ values of acarbose against $\alpha$-glucosidase and $\alpha$-amylase were 643.7 and $59.1 \mathrm{mg} \mathrm{L}^{-1}$, respectively.

\subsection{Statistical Analysis}

All results presented are the means \pm standard deviations of the three independent experiments. Regression analysis between chemical contents versus biological activities and statistical analysis was carried out using Microsoft Excel 2010.

\section{Results and Discussion}

\section{1. pH Value and Toxic Metal Levels of Syrup}

Prepared mulberry syrup is slightly acidic due to fermentation by the yeast present in fresh fruit [18]. The $\mathrm{pH}$ of the syrup shows a tendency to decrease over time. Toxic metals such as lead $(\mathrm{Pb})$ and cadmium $(\mathrm{Cd})$ may be present in food naturally or as a result of food processing. Heavy metals in glass-clay containers can be transferred to food by a pH-dependent leaching process [19]. Therefore, the $\mathrm{Pb}$ and $\mathrm{Cd}$ contents of mulberry syrup were evaluated. The $\mathrm{Pb}$ concentration increased from 12.4 to $19.5 \mu \mathrm{g} \mathrm{L}^{-1}$ while the Cd level increased slightly (Table 1). According to Vietnam National Technical Regulations on heavy metal contamination in food, the maximum acceptable concentration of $\mathrm{Pb}$ in fruit juices and nectars is $200 \mu \mathrm{g} \mathrm{L}^{-1}$. Although no such guideline is available for $\mathrm{Cd}$, the regulatory limit for $\mathrm{Cd}$ in drinking water is $3 \mu \mathrm{g} \mathrm{L}^{-1}$ [20]. Thus, the $\mathrm{Pb}$ and $\mathrm{Cd}$ levels in mulberry syrup were acceptable. However, prolonged storage of the syrup in glass containers can cause leaching of $\mathrm{Pb}$ and other toxic metals, which represents a risk to the health of consumers.

Table 1. pH values and toxic metal contents in mulberry syrups during the storage

\begin{tabular}{cccc}
\hline Time (days) & $\mathrm{pH}$ & $\mathrm{Pb}(\mu \mathrm{g} / \mathrm{L})$ & $\mathrm{Cd}(\mu \mathrm{g} / \mathrm{L})$ \\
\hline 15 & $6.35 \pm 0.49$ & $12.41 \pm 1.81$ & $1.05 \pm 0.06$ \\
30 & $6.11 \pm 0.57$ & $12.65 \pm 0.96$ & $1.10 \pm 0.08$ \\
45 & $5.86 \pm 0.51$ & $14.58 \pm 1.39$ & $1.18 \pm 0.11$ \\
60 & $5.42 \pm 0.38$ & $17.21 \pm 2.08$ & $1.35 \pm 0.08$ \\
90 & $4.73 \pm 0.41$ & $19.54 \pm 2.17$ & $1.66 \pm 0.12$ \\
\hline
\end{tabular}

\subsection{Total Phenolic, Flavonoid and Anthocyanin Contents}

The change in contents of phenolics, flavonoids and anthocyanins in the mulberry syrup was evaluated over 90 days (Figure 1). The total phenolic content (TPC) of the mulberry syrup increased from $1,862.6 \mathrm{mg}$ gallic acid equivalent (GAE) $\mathrm{L}^{-1}$ at day 15 to $2,045.1 \mathrm{mg} \mathrm{GAE} \mathrm{L}^{-1}$ at day 30, and decreased after day 45 (Figure 1). At day 90, the TPC was $34.2 \%$ lower than that at day 15 (1,225.1 vs. 1,862.6 mg GAE $\mathrm{L}^{-1}$ ). The total flavonoid content (TFC) of the mulberry syrup increased to $1,284.7 \mathrm{mg}$ quercetin equivalents (QE) $\mathrm{L}^{-1}$ at day 30 and decreased gradually to $624.1 \mathrm{mg} \mathrm{QE} \mathrm{L}^{-1}$ at day 90. The increases in TPC and TFC may have been due to fermentation by yeast [18,21]. High levels of phenolic acids and flavonoids (e.g., syringic acid, protocatechuic acid, hydroxycinnamic acid, chlorogenic acid, ferulic acid, quercetin, and morin) are reportedly present in fermented mulberry products [22].

The fermentation of mulberry juice is typically accelerated by adding lactic acid bacteria $[23,24]$. In this study, due to the low concentration of bacteria the mulberry syrup was fermented by the yeast present on the mulberry fruit. The reduction in TPC and TFC at day 30 was likely due to the weak fermentative activity, and prolonged exposure to light and atmospheric oxygen. Darias-Martin et al. reported that alcoholic beverages produced using the native yeast of black mulberry juice were of poor quality [18]. However, the fermentation duration and parameters measured were not provided. The total anthocyanin content (TAC) of the mulberry syrup decreased by $75.5 \%$ at 90 days (from 985.0 to $240.6 \mathrm{mg}$ C3G equivalent $\mathrm{L}^{-1}$ ). The stability of anthocyanins is affected by their structure, as well as the $\mathrm{pH}$, temperature, light and oxygen levels, and inter- and intra-molecular associations with other compounds [25]. The TAC of mulberry juice reportedly decreased by $99 \%$ after 8 weeks of storage at $30^{\circ} \mathrm{C}[26]$.
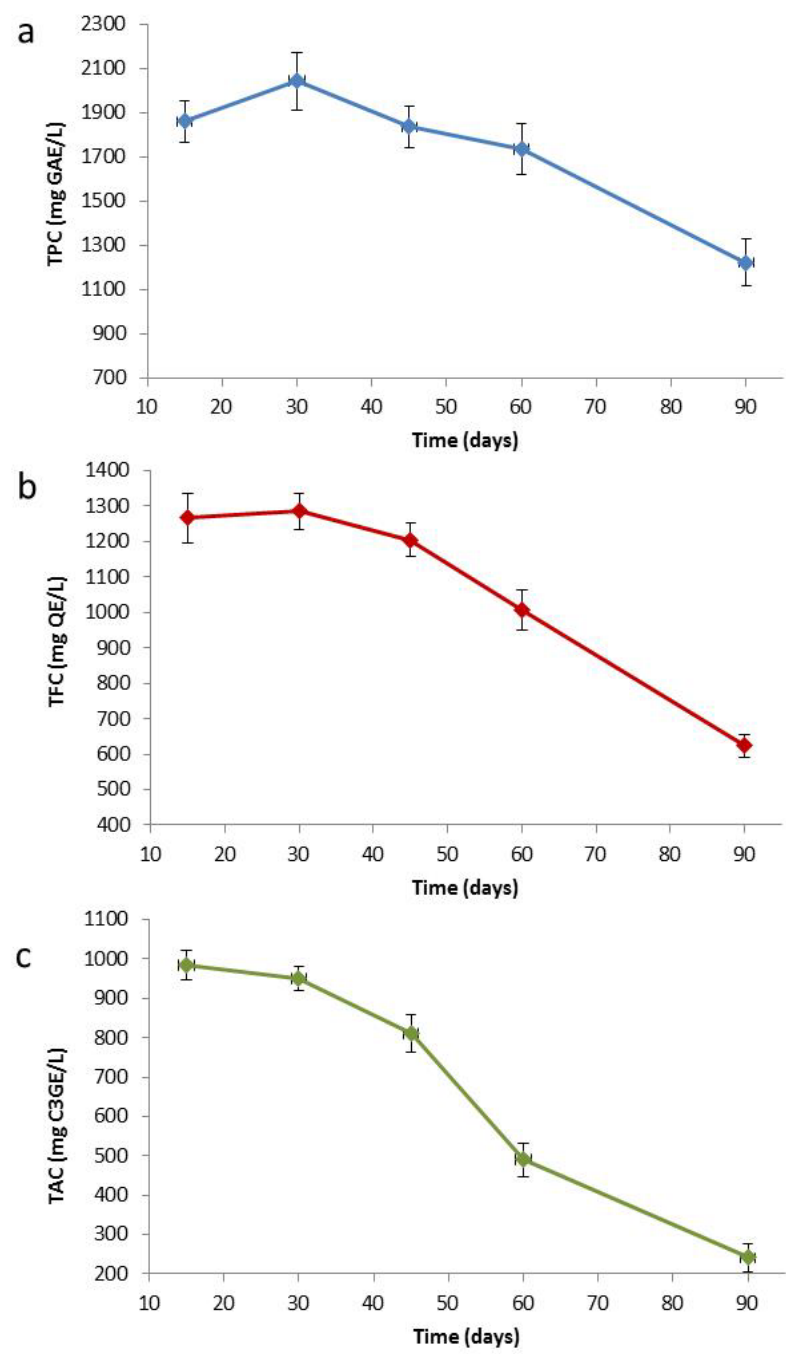

Figure 1. Changes in TPC (a), TFC (b) and TAC (c) of mulberry syrup during storage. GAE: gallic acid equivalent, QE: quercetin equivalent, C3GE: cyanidin-3-O-glucoside equivalent. Bars are standard deviations $(n=3)$ 


\subsection{Biological Activities of Mulberry Syrup}

Four assays were used to evaluate the biological activities of mulberry syrup during storage. The antioxidant activity of the mulberry syrup was evaluated by the 1,1-diphenyl2-picryl-hydrazyl (DPPH) assay. The antioxidant activity of the syrup increased until day 30 and decreased slightly thereafter (Figure 2a). The DPPH-scavenging capacity of the mulberry syrup decreased by $16.3 \%$ from day 15 (2.88 $\mathrm{mg}$ L-ascorbic acid equivalent [AAE] $\mathrm{L}^{-1}$ ) to day 90 (2.41 mg AAE $\mathrm{L}^{-1}$ ). This is consistent with previous reports that the antioxidant activity of mulberry is linearly proportional to its phenolic content $[26,27,28]$. Scatterplots showed high correlations $\left(r^{2}>0.93\right)$ between the antioxidant activity of mulberry syrup and its TPC, TFC, and TAC values (Table 2).
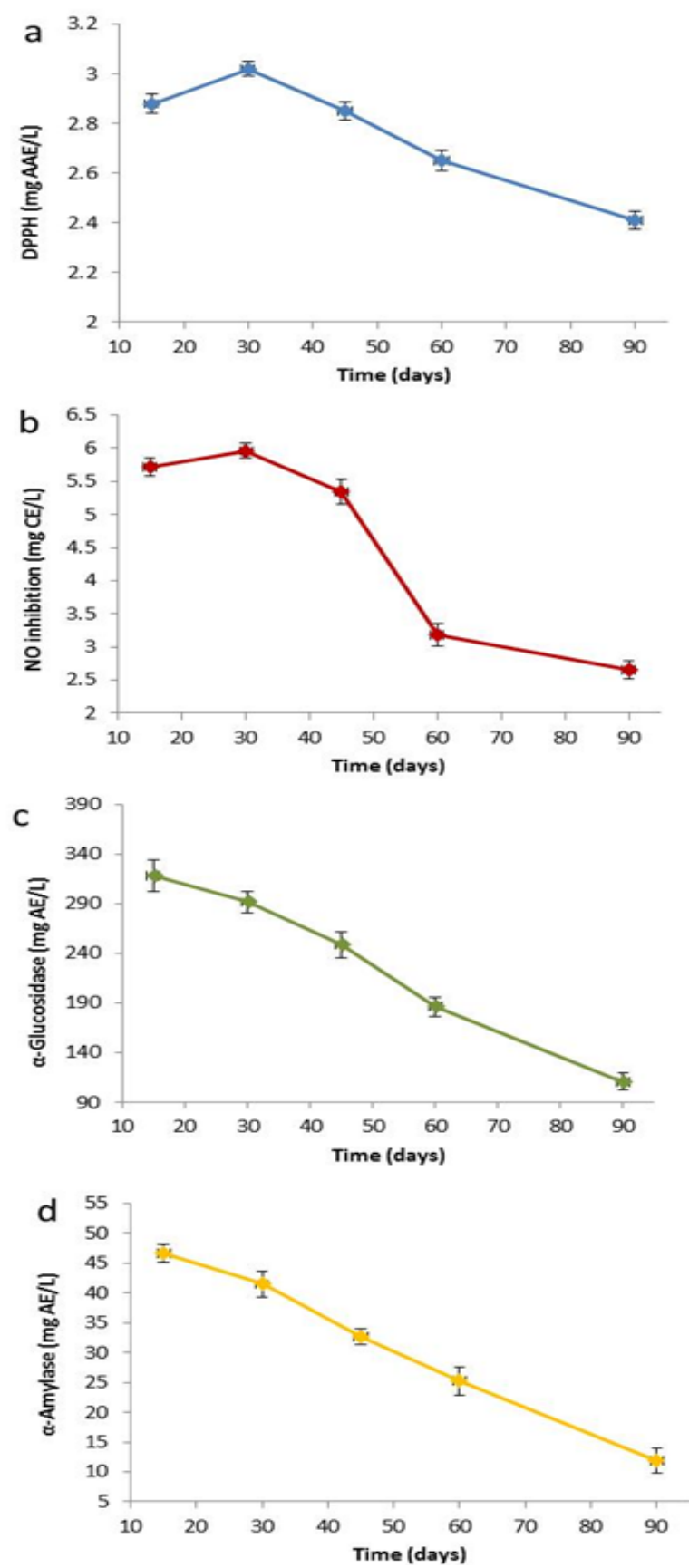

Figure 2. Changes in DPPH radical-scavenging activity (a), NO inhibitory activity (b) and inhibition of $\alpha$-glucosidase (c) and $\alpha$-amylase (d) of mulberry syrup during storage. Bars are standard deviations $(n=3)$
Table 2. Correlation rates $\left(r^{2}\right)$ between chemical compositions and biological activities of mulberry syrup

\begin{tabular}{ccccc}
\hline & DPPH & NO & $\alpha$-Glucosidase & $\alpha$-Amylase \\
\hline TPC & 0.9337 & 0.7362 & 0.8048 & 0.7935 \\
TFC & 0.9441 & 0.8567 & 0.9247 & 0.903 \\
TAC & 0.9304 & 0.9616 & 0.9854 & 0.9617 \\
\hline
\end{tabular}

Anti-inflammation is also an important property of mulberry fruit. We assayed the inhibition of nitric oxide (NO) production by mulberry fruit to evaluate its anti-inflammatory activity [29]. The temporal pattern of NO inhibition by mulberry syrup was similar to that of its antioxidant activity (Figure 2b). The anti-inflammatory activity of the syrup was correlated with its anthocyanin $\left(r^{2}=0.9616\right)$ but not its phenolic and flavonoid $\left(r^{2}=0.73-0.85\right)$ contents. Anthocyanin-rich fractions and C3G reportedly inhibit $\mathrm{NO}$ and attenuate inflammation both in vitro and in animal models [30,31,32].

Mulberry fruit is also a good source of antidiabetic agents [33], including inhibitors of the enzymes responsible for carbohydrate hydrolysis such as $\alpha$-glucosidase and $\alpha$-amylase [34]. Inhibition by the mulberry syrup of $\alpha$-glucosidase and $\alpha$-amylase activity gradually decreased

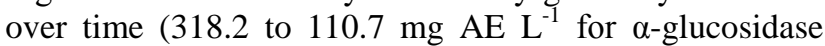
and 46.7 to $11.9 \mathrm{mg} \mathrm{AE} \mathrm{L}^{-1}$ for $\alpha$-amylase; Figure 2c and d). The TFC and TAC values were linearly correlated $\left(\mathrm{r}^{2}>0.90-0.98\right)$ with the magnitude of the inhibition of $\alpha$-glucosidase and $\alpha$-amylase activity. Quercetin and galloylcyanidin-glycoside are potent inhibitors of $\alpha$-glucosidase $[33,35,36]$. Jin et al. reported that the $\alpha$-glucosidase inhibitory activity of mulberry fruit was positively correlated with the levels of C3G, C3R, pelargonidin 3-O-glucoside, and pelargonidin 3-O-rutinoside [37].

\section{Conclusion}

The quality of mulberry syrup was evaluated by investigating its chemical composition and in vitro biological activities. The mulberry syrup contained considerable amounts of phenolic, flavonoid, and anthocyanin compounds. The levels of these constituents were stable during the first 30 days but decreased significantly after day 45. Similarly, the antioxidant, anti-inflammatory, and antidiabetic activities of the mulberry syrup were high during the first 30 days. $\mathrm{Pb}$ and $\mathrm{Cd}$ were found to have leached from the glass container into the syrup during storage. Our results suggest that prolonged storage of mulberry syrup reduces the levels of bioactive compounds and its health-promoting effects.

\section{Conflict of Interest}

The authors declare that they have no conflict of interest.

\section{Acknowledgements}

This work is supported by a grant from the Vietnam Academy of Science and Technology (VAST.TD.TP.01/16-18). 


\section{References}

[1] Zhang, H., Ma, Z. F., Luo, X. and Li, X., "Effects of Mulberry Fruit (Morus alba L.) Consumption on Health Outcomes: A MiniReview,” Antioxidants, 7, E69, 2018.

[2] Yuan, Q. and Zhao, L., "The Mulberry (Morus alba L.) Fruit-a review of characteristic components and health benefits," J. Agric. Food Chem., 65(48), 10383-10394, 2017.

[3] Ercisli, S. and Orhan, E., "Chemical composition of white (Morus alba) red (Morus rubra) and black (Morus nigra) mulberry fruits," Food Chem., 103, 1380-1384, 2007.

[4] Gundogdu, M., Muradoglu, F., Gazioglu Sensoy, R. I. and Yilmaz, H., "Determination of fruit chemical properties of Morus nigra L., Morus alba L. and Morus rubra L. by HPLC,” Sci. Hortic., 132, 37-41, 2011.

[5] Ozgen, M., Serce, S. and Kaya, C., "Phytochemical and antioxidant properties of anthocyanin-rich Morus nigra and Morus rubra fruits," Sci. Hortic., 119, 275-279, 2009.

[6] Stefanut, M. N., Cata, A., Pop, R. and Mosoarca, C. and Zamfir, A. D., "Anthocyanins HPLC-DAD and MS characterization, total phenolics, and antioxidant activity of some berries extracts,” Anal. Lett., 44, 2843-2855, 2011.

[7] Xiao, T., Guo, Z., Sun, B. and Zhao, Y., "Identification of Anthocyanins from Four Kinds of Berries and Their Inhibition Activity to $\alpha$-Glycosidase and Protein Tyrosine Phosphatase 1B by HPLC-FT-ICR MS/MS,” J. Agric. Food Chem., 65(30), 6211-6221, 2017.

[8] Vo, V. C., Dictionary of Vietnamese Medicinal Plants, vol. I. Medicine Publisher: Hanoi, Vietnam, 2012, 175-176.

[9] Lim, T. K., Morus nigra, In: Edible Medicinal and Non Medicinal Plants, Lim, T. K., eds, Springer: Dordrecht, 2012, 430-438.

[10] Do, T. L., Medicinal Plants and Remedies in Viet Nam, Medicine Publisher: Hanoi, Vietnam, 2004, 720-721.

[11] ISO 14502-1, Determination of substances characteristic of green and black tea. Part 1: Content of total polyphenols in tea. Colorimetric method using Folin-Ciocalteu reagent. 2005.

[12] Hosu, A., Cristea, V. M. and Cimpoiu, C., "Analysis of total phenolic, flavonoids, anthocyanins and tannins content in Romanian red wines: prediction of antioxidant activities and classification of wines using artificial neural networks," Food Chem., 150, 113-118, 2014.

[13] Lee, J., Durst, R. W. and Wrolstad, R. E., “Determination of total monomeric anthocyanin pigment content of fruit juices, beverages, natural colorants, and wines by the $\mathrm{pH}$ differential method: collaborative study,” J. AOAC Int., 88(5), 1269-1278, 2005.

[14] Geana, I., Iordache, A., Ionete, R., Marinescu, A., Ranca, A. and Culea, M., "Geographical origin identification of Romanian wines by ICP-MS elemental analysis,” Food Chem., 138, 1125-1134, 2013.

[15] Huong, T. T., Cuong, N. X., Tram, L. H., Quang, T. T., Duong, L. V., Nam, N. H., Dat, N. T., Huong, P. T., Diep, C. N., Kiem, P.V. and Minh, C. V., "A new prenylated aurone from Artocarpus altilis,” J. Asian Nat. Prod. Res., 14(9), 923-928, 2012.

[16] Dat, N. T., Binh, P. T., Quynh, L. T. P., Huong, H. T. and Minh, C. V., "Sanggenon C and O inhibit NO production, iNOS expression and NF- $\mathrm{B}$ activation in LPS-induced RAW264.7 cells," Immunopharmacol. Immunotoxicol., 34(1), 84-88, 2012.

[17] Hanh, T. T. H., Dang, N. H. and Dat, N. T., " $\alpha$-Amylase and $\alpha$-glucosidase inhibitory saponins from Polyscias fruticosa leaves," J. Chem., 2082946, 2016.

[18] Darias-Martin, J., Lobo-Rodrigo, G., Hernandez-Cordero, J., DiazDiaz, E. and Diaz-Romero, C., "Alcoholic beverages obtained from black mulberry,” Food Technol. Biotech., 41(2), 173-176, 2003.

[19] Valadez-Vega, C., Zuniga-Perez, C., Quintanar-Gomez, S., Morales-Gonzalez, J. A. and Madrigal-Santillan, E., VillagomezIbarra, J. R., Sumaya-Martinez, M. T., Garcia-Paredes, J. D., "Lead, cadmium and cobalt $(\mathrm{Pb}, \mathrm{Cd}$, and $\mathrm{Co})$ leaching of glass- clay containers by $\mathrm{pH}$ effect of food,” Int. J. Mol. Sci., 12(4), 2336-2350, 2011.

[20] QCVN 8-2:2011/BYT, National technical regulation on the limits of heavy metals contamination in food, 2011.

[21] Heard, G., "Novel yeasts in winemaking - looking to the future," Food Australia, 51, 347-352, 1999.

[22] Juan, C., Jianquan, K., Junni, T., Zijian, C. and Ji, L., "The profile in polyphenols and volatile compounds in alcoholic beverages from different cultivars of mulberry,” J. Food Sci., 77(4), C430-436, 2012.

[23] Kwaw, E., Ma, Y., Tchabo, W., Apaliya, M. T., Wu, M., Sackey, A. S., Xiao, L. and Tahir, H. E., "Effect of lactobacillus strains on phenolic profile, color attributes and antioxidant activities of lactic-acid-fermented mulberry juice,” Food Chem., 250, 148-154, 2018.

[24] Nguyen, C. L. and Nguyen, H. V. H., "The quality of mulberry juice as affected by enzyme treatments,” Beverages, 4, 41, 2018.

[25] Burton-Freeman, B., Sandhu, A., Edirisinghe, I., Anthocyanins, In: Nutraceuticals: Efficacy, Safety and Toxicity, Gupta, R. C., eds, Academic Press: London, 2016, 489-500.

[26] Zou, B., Xu, Y. J., Wu, J. J., Yu, Y. S. and Xiao, G. S., "Phenolic compounds participating in mulberry juice sediment formation during storage,” J. Zheijang Univ. Sci. B, 18(10), 854-866, 2017.

[27] Tomas, M., Toydemir, G., Boyacioglu, D., Hall, R., Beekwilder, J. and Capanoglu, E., "The effects of juice processing on black mulberry antioxidants,” Food Chem., 186, 277-284, 2015.

[28] Zhang, L., Li, N. and Gao, X., "Phenolic compounds and antioxidant activity of wines fermented using ten blueberry varieties, ” Am. J. Food Tech., 12, 367-373, 2012.

[29] Luiking, Y. C., Engelen, M. P. and Deutz, N. E., "Regulation of nitric oxide production in health and disease,” Curr. Opin. Clin. Nutr. Metab. Care, 13, 97-104, 2010.

[30] Li, L., Wang, L., Wu, Z., Yao, L., Wu, Y., Huang, L., Liu, K., Zhou, X. and Gou, D., "Anthocyanin-rich fractions from red raspberries attenuate inflammation in both RAW264.7 macrophages and a mouse model of colitis,” Sci. Rep., 4, 6234, 2014.

[31] Hassimotto, N. M., Moreira, V., do Nascimento, N. G., Souto, P. C., Teixeira, C. and Lajolo, F. M., "Inhibition of carrageenaninduced acute inflammation in mice by oral administration of anthocyanin mixture from wild mulberry and cyanidin-3glucoside,” BioMed Res. Int., 2013, 146716, 2013.

[32] Qian, Z., Wu, Z., Huang, L., Qiu, H., Wang, L., Li, L., Yao, L., Kang, K., Qu, J., Wu, Y., Luo, J., Liu, J. J., Yang, Y., Yang, W. and Gou, D., "Mulberry fruit prevents LPS-induced NF- $\mathrm{B} / \mathrm{pERK} / \mathrm{MAPK}$ signals in macrophages and suppresses acute colitis and colorectal tumorigenesis in mice," Sci. Rep., 5, 17348, 2015.

[33] Wang, Y., Xiang, L., Wang, C., Tang, C. and He, X., "Antidiabetic and antioxidant effects and phytochemicals of mulberry fruit (Morus alba L.) polyphenol enhanced extract," PLoS One, 8(7), e71144, 2013.

[34] Tundis, R., Loizzo, M. R. and Menichini, F., "Natural products as alpha-amylase and alpha-glucosidase inhibitors and their hypoglycaemic potential in the treatment of diabetes: an update," Mini Rev. Med. Chem., 10(4), 315-331, 2010.

[35] Li, F., Zhang, B., Chen, G. and Fu, X., "The novel contributors of anti-diabetic potential in mulberry polyphenols revealed by UHPLC-HR-ESI-TOF-MS/MS,” Food Res. Int., 100, 873-884, 2017.

[36] Xiao, T., Guo, Z., Sun, B. and Zhao, Y., "Identification of anthocyanins from four kinds of berries and their inhibition activity to $\alpha$-glycosidase and protein tyrosine phosphatase $1 \mathrm{~B}$ by HPLC-FT-ICR MS/MS,” J. Agric. Food Chem., 65(30), 6211-6221, 2017.

[37] Jin, Q., Yang, J., Ma, L., Cai, J. and Li, J., “Comparison of polyphenol profile and inhibitory activities against oxidation and $\alpha$-glucosidase in mulberry (genus morus) cultivars from China," $J$. Food Sci., 80(11), C2440-2451, 2015. 